\section{Playing and Reality}

\section{W. WINNICOTT}

Dr. Winnicott's presentation of his theme, vividly illustrated from clinical material, conveys the sense of the magic of living - the joie de vivrewe all intuitively seek. The book constitutes an impressive addition to this author's published work. Its appeal, like its subject-matter, is universal. $£ 2.10$ net

Forthcoming in May.

\section{Mental Illness in Childhood}

A STUDY OF RESIDENTIAL TREATMENT

\section{L. KAHAN}

This pioneering work demonstrates the therapeutic potential of the total environment in the management of mental illness in children, and provides a model that has many applications to other forms of residential treatment. Mind and Medicine Monographs, 21 . £3.00 net

\section{Young Children in Hospital}

\section{Second Edition}

With a Postscript 1970

\section{JAMES ROBERTSON}

'All doctors, nurses and those concerned with hospital administration or who share some responsibility for the care of children in hospital will welcome this excellent book.' International Journal of Health Education. Social Science Paperback 8op net

\section{Towards Community Mental Health}

Edited by

JOHN D. SUTHERLAND

Elizabeth Bott, Barbara Butler, Geoffrey Gorer, Elliott Jaques, Ben Morris, Herbert Phillipson, John D. Sutherland, and D. W. Winnicott consider from their different professional viewpoints ways of helping individuals and groups to meet the stresses of a technological society. $\AA^{2.40}$ net

\section{Family and Social Network}

\section{Second Edition}

With a Preface by Max Gluckman ELIZABETH BOTT

'It has become a classic and is as fresh to read now as when it was first published.' $K$. McDougall, Case Conference. £3.25; Social Science Paperback $£$ I.50 net

\section{On Death and Dying ELISABETH KÜBLER-ROSS}

With an Introduction by C. Murray Parkes

'The book is for doctors, nurses and families-for all who have to care for or be with the dying. It is also, by implication, a book for anyone concerned with the function of our hospitals.' The Hospital Er.90 net

TAVISTOCK PUBLICATIONS

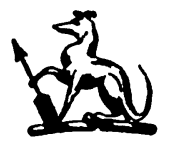


Brit. J. Pychiat. (1971), 118, 483-4

\section{Books Received}

Telepathic Impressions: A Review and Report of 35 New Cases. By Ian Stevenson. University Press of Virginia. Price \$6.50.

Carmichael's Manual of Child Psychology. Edited by Paur H. Mussen. (Vols. I and 2.) Third edition. John Wiley and Sons. Price £i3.25 (Vol. 1) and f8.75 (Vol. 2).

Homo Psychologicus. By John Cohen. George Allen $\mathbb{E}$ Unwin. Price $£ 2.50$.

Mental Imagery in the Child. By Jean Piaget and Barbel Inhelder. Routledge and Kegan Paul. Price $£ 3.50$.

Kybernetics of Mind and Brain. By D. StanleyJones. Charles C. Thomas. Price \$10.75.

On Intelligence: Proceedings of the Toronto Symposium on Intelligence, 1969. Edited by W. B. DockrelL. Methuen. Price £3.00.

Origins of Psychopharmacology from CPZ to LSD. By Anne E. Galdwell. Charles C. Thomas. Price \$12.00.

No Language but a Cry. By Richard D'Ambrosio. Cassell. Price £2.10.

Angiography of the Mesencephalon. By A. WACKENHEM and J. P. BRAUN. Springer. Price DM 98.

The World Biennial of Psychiatry and Psychotherapy. Volume I. Edited by Sinvano Armetr. Basic Books. Price $£ 9.35$.

A Place like Home: A Pioneer Hostel for Boys. By W. Davm Wils. George Allen $\mathcal{E}$ Unwin. Price $£ \mathrm{I} .75$.

The Unresponsive Bystander: Why Doesn't he Help? By Bibb Latane and John M. Darley. AppletonCentury-Crofts. Price \$4.95.

Computers and Brains. Edited by J. P. Schadé and J. Surtr. (Progress in Brain Research, Volume 33.) Elsevier. Price $£ 9.50$.

The Briefer Psychotherapies. By Leonard Small. Brunner/Mazel. Price \$7.50.

Addiction and Society. By Nns Bejerot. Charles $C$. Thomas. Price \$9.75.

Readings in Extraversion-Introversion. 1. Theoretical and Methodological Issues. Edited by H. J. Eysencr. Granada Publishing Company. Price $£ 4.00$.

Perception, Motives and Personality. By Grorgr S. KleIn. Alfred A. Knopf. No price stated.

Paychologic Cues in Forecasting Physical Illness. By Samuel Silverman. Buttenworth. Price $£ 5.50$.

Migraine: Evolution of a Common Disorder. By Ourver W. SAcks. Faber. Price £2.50.

Pharmacotherapy of Tension and Anxiety. By Hennz E. Lehmann and Thomas A. BAn. Charles $C$. Thomas. Price \$7.50.

A Psychiatric Record Manual for the Hospital. By Dorothy Surth Krller. University of Pittsburgh Press. Price \$8.50.
The Family and its Future (Proceedings of a Ciba Foundation Symposium, March 1970). Edited by Katherine Ellotr. 7. \& A. Churchill. Price $£ 3.00$

Studies in Human Sexual Behaviour: The American Scene. Edited by Anon Shror. Charles C. Thomas. Price \$16.50.

International Journal of Psychiatry: Current Issues in Psychiatry: Volume Nine. Edited by Jason Aronson. Science House. Price \$20.00.

Magical Medicine: A Nigerian Case-study. By UNA Maclean. Allen Lane The Penguin Press. Price $£ 2.50$.

New Aspects of Storage and Release Mechanisms of Catecholamines. Edited by H. J. SchümanN and G. Kroneberg. Springer. Price DM 48.

The Alcoholic and the Help he Needs. By MAx Glatt. (Part I.) Priory Press. Price 50p.

Behaviour Therapy and the Law: Proceedings of a Symposium held in October 1969 , under the auspices of the Manchester Branch of the Division of Clinical Psychology of the British Psychological Society. Edited by Laurence E. Burns and James L. Worsley. John Wright. Price £2.00.

The Geriatric Day Hospital. By J. C. Brockuehurst. King Edward's Hospital Fund for London. Price $£^{1}$.10.

Genetic Counselling in Relation to Mental Retardation: Proceedings of a Symposium held in March 1969 under the auspices of the Institute of Research into Mental Retardation. Edited by J. M. Berg. Pergamon Press. Price 75p.

Biochemical Screening in Relation to Mental Retardation: Proceedings of a Symposium held in May 1969 under the auspices of the Institute for Research into Mental Retardation. Edited by D. C. Cusworth. Pergamon Press. Price 9op.

Toward a Public Policy on Mental Health Care of the Elderly. GAP Report No. 79. Group for the Advancement of Psychiatry. Price \$1.00.

Ego Boundaries. By Bernard Landis. Psychological Issues. Vol. VI. No. 4. Monograph 24. International Universities Press. Price \$4.50.

Proceedings of the Fifth Conference of the Association for the Psychiatric Study of Adolescents. Edingburgh, 1970. Edited by D. O. FidDes. Association for the Psychiatric Study of Adolescents. Price $£$ I.00.

Eighteenth Report of the WHO Expert Committee on Drug Dependence. World Health Organization Technical Report Series No. 460. Price 30p.

Pour une Psychiatrie Communautaire. By JAcQues Hochmann. Editions du Seuil, Paris. No price stated. 
Hypochondrie: Melancholie bis Neurose; Krankheiten und Zustandsbilder. By EsTHer Fischer-Homberorr. Huber. Price DM 23.

Medizinische Psychologie. By Ernst Kretschumer. Georg Thieme. Price DM 39.

Transkulturelle Paychiatrie: Ergebnisse und Probleme. By Wolronno M. Preiffer. Georg Thieme. Price DM 39.60.
Nicotinic Acid in the Treatment of Schizophrenias: Canadian Mental Health Association Collaborative Study Progress Report I. By Thomas A. BAN and Heinz E. Lemmann. Canadian Mental Health Assaciation. Price $\$ 2.00$, plus $\cdot 50$ postage and handling.

Tropical Doctor, Vol. I, No. I. Edited by H. A. Cuzoo. Royal Society of Medicine. Price 75p. (Annual subscription for four quarterly issues $£ 3.00$.)

Many of these books will be reviewed at a later date. 